\title{
UNRAVELING THE RIGHT TO LIFE IN CASES OF DEATHS RESULTING FROM THE ACTIONS OF STATE AGENTS UNDER THE SYSTEM OF ECHR
}

\author{
Prischa Listiningrum ${ }^{1}$ \\ ${ }^{1}$ Student of Master of Laws (LLM) in the University of Edinburgh, \\ the United Kingdom.
}

Email : p.listiningrum@gmail.com

Submitted : 17-02-2017 | Accepted: 02-03-2017

\begin{abstract}
Article 2 of the ECHR regulates the right to life as a fundamental right that the deprivation of it shall be done in a certain threshold of necessity. In particular when the taken of life is done by the agents of states. This article examines the interpretation of article 2 by the European Court of Human Rights, especially when it is read in conjunction with state's positive obligations under article 1. The discussion will proceed in three sections: first, the review of the evolvement of the procedural requirements of article 2 in cases of deaths arising from the acts of state agents. Second, is the examination of whether the procedural requirements of article 2 can be used as a mean in securing the adequate protection of the right to life from arbitrary killing by the use of lethal force? Third, is an analysis of an effective legal system as a procedural requirement of article 2 in the case of homicide caused by the negligence of the authorities? Finally, this essay will conclude by examining the Court's position in its endeavors to achieve an appropriate balance between not over-burdening its Member States and securing the adequate protection of the right to life.

This research submitted that when article 2 it is read together with positive obligation of states under article 1, duty to investigate emerges as a consequence. Development shows that the Court has a distinct approach in setting a minimum standard for the states to adhere to.
\end{abstract}

Keyword: right to life, human rights, European, constitution

\section{INTRODUCTION}

The right to life is one of the most fundamental provisions of the European Convention on Human Rights (hereinafter

\footnotetext{
${ }^{1}$ McCann and Others $v$. the United Kingdom, no. 18984/91, § 53, 27 September 1995; Cakici v. Turkey, no. 23657/94, § 86, 8 July 1999; McKerr v. the United Kingdom, no. 28883/95, § 108, 4 May 2001; Hugh Jordan v. the United Kingdom, no. 24746/94, § 102, 4 May 2001; Kelly and Others v. the United Kingdom, no. 30054/96, § 91, 4 May 2001; Shanaghan v. the United Kingdom, no. 37715/97, § 85, 4 May 2001; Isayeva v. Russia, no. 57950/00, § 172, 24 February 2005; Isayeva, and
}

"ECHR"). ${ }^{1}$ No deprivation of life can be conducted intentionally, except in certain conditions as stated in article 2 paragraph 2, which gives a privilege for states to take one's life if it is "absolutely necessary",

Others v. Russia, nos. 57947/00, 57948/00 and 57949/00, § 168, 24 February 2005; Leonidis $v$. Greece, no. 43326/05, § 53, 8 January 2009. See also DJ Harris and others, Law of the European Convention on Human Rights (3rd edn, OUP 2014) 203; and FD Sanctis, 'What Duties do States have with Regard To the Rules of Engagement and the Training of Security Forces under Article 2 of the European Convention on Human Rights?' (2006) 101 The International Journal of Human Rights 31. 
such as in defense of others, effecting lawful detention, and in overcoming riot or insurrection. $^{2}$ Moreover, article 15 paragraph 2 also justifies the deprivation of life by states in the time of war. ${ }^{3}$ It means that the right to life is not absolute in its nature. ${ }^{4}$ However, in order to secure the enjoyment of the right to life, there should be a procedure to examine the legitimating of the taking of life by use of lethal force.

\section{The European Court of Human} Rights (hereinafter "the Court"), in its verdicts, indicates an importance of duty to investigate, as a procedural obligation of the right to life, when it is taken by the use of force. ${ }^{5}$ This principle was generated after the Court interpreted the protection of the right to life under article 2 in conjunction with the state's obligation in securing the Convention's rights within its jurisdiction under article 1. The term "jurisdiction" enables the Court to expand

\footnotetext{
${ }^{2}$ European Convention on Human Rights, Article 2.

${ }^{3}$ ibid Article 15 paragraph 2.

${ }^{4}$ FN Aolain, 'The Evolving Jurisprudence of the European Convention Concerning the Right to Life' (2001) 19/1 Netherlands Quarterly of Human Rights 21, 22-3.

${ }^{5}$ See McCann and Others $v$. the United Kingdom (n 1) $\S 161$; Kaya v. Turkey, no. 22729/93, § 86, 19 February 1998; Ergi v. Turkey, no. 23818/94, § 82, 28 July 1998; Çakici v. Turkey (n 1); Tanrikulu v. Turkey, no. 23763/94, § 101, 8 July 1999; McKerr v. the United Kingdom (n 1) § 111; Hugh Jordan v. the United Kingdom (n 1) $\$ 105$; Kelly and Others v. the United Kingdom (n 1) § 94; Shanaghan v. the United Kingdom (n 1) § 88; Anguelova v. Bulgaria, no. 38361/97, § 136, 13 June 2001; Ulku Ekinci v. Turkey, no. 27602/95, § 144, 16 July 2002; Hackett v. the United Kingdom, no. 34698/04, admissibility decision of 10 May 2005; Nachova and Others $v$.
}

the application of this procedural obligation to extraterritorial actions of state agents. ${ }^{6}$

Essentially, an obligation to investigate deaths resulting from the actions of state agents is vital in maintaining public trust of a democratic society, because ordinarily the state is the only entity that monopolises the use of lethal force. ${ }^{7}$ In this context, an effective official investigation can be used as a means of ensuring the legitimate aims of the authorities in taking a life. Subsequently, there will be a degree of certainty that the authorities will not abuse their power.

Moreover, leaving the families of the deceased uninformed regarding the circumstances of the deaths may also torture them mentally. Therefore, recalling the importance of transparency and adequate information for the families of the

Bulgaria, nos. $43577 / 98$ and 43579/98, § 110, 6 July 2005; Ramsahai v. the Netherlands, no. 52391/99, § 321, 15 May 2007; Al-Skeni v. the United Kingdom, no. 55721/07, § 163, 7 July 2011. 6 ibid $\S 149$. See also C Ryngaert, 'Claritying the Extraterritorial Application of the European Convention on Human Rights' (2012) 28/74 Merkourios 57, 59; A Cowan, 'A New Watershed? Re-evaluating Bankovic in Light of Al-Skeni' (2012) (1)1 Cambridge Journal of International and Comparative Law 213, 219.

${ }^{7}$ See McKerr $v$. the United Kingdom (n 1) § 114; Hugh Jordan v. the United Kingdom (n 1) § 114; Kelly and Others $v$. the United Kingdom (n 1) § 117; Shanaghan v. the United Kingdom (n 1) § 91; May 2001; Anguelova v. Bulgaria (n 5); Ramsahai v. the Netherlands (n 5) $\S \S 321,324$; Al-Skeni v. the United Kingdom (n 5) § 167. 
deceased, the Court extends the procedural obligation of the right to life to any case of deaths caused by state agents, even on nonlethal force incidences. In some recent jurisprudence, the Court requires an effective official investigation for the case of sudden death resulting from medical or surgical intervention ${ }^{8}$ and in the case of unexpected homicide caused by authorities' negligence, such as abandoning citizens living in a lifethreatening environmental condition. ${ }^{9}$

Despite its robust judgments, protecting the right to life is not an easy task for the Court. On one hand the Court has to set a minimum standard on the protection of the right to life. On the other hand the Court could not impose upon states an impossible or disproportionate burden. ${ }^{10}$ It should be borne in mind that the 47 member states ${ }^{11}$ of the Convention will have different capacities and capabilities in managing their societies. Therefore, this essay aims to analyse whether the Court has achieved an appropriate balance between not over-

\footnotetext{
${ }^{8}$ See Erikson v. Italy, no. 37900/97, admissibility decision of 26 October 1999. See also D Korff, 'The Right to Life: A Guide to the Implementation of Article 2 of the European Convention on Human Rights' (2006) 8 Human rights handbooks 75; J Chevalier-Watts, 'Effective Investigations under Article 2 of the European Convention on Human Rights: Securing the Right to Life or an Onerous Burden on a State?' (2010) 213 The European Journal of International Law 701, 707; and T McGleenan, Investigating Deaths in Hospital in
}

burdening its Member States and securing the adequate protection of the right to life in cases of deaths resulting from the actions of state agents.

The analysis will be based on the review of the judgments of the Court, relating to the interpretation of the right to life, under article 2 of the ECHR when it is read together with article 1 . The discussion will proceed in three sections: first, the review of the evolvement of the procedural requirements of article 2 in cases of deaths arising from the actions of state agents. Second, is the examination of whether the Court has reached a balance between not over-burdening its Member States and securing the adequate protection of the right to life from arbitrary killing by the use of lethal force. Third, is an analysis of an effective legal system as a procedural requirement of article 2 in the case of homicide caused by the negligence of the authorities. Finally, this essay will conclude by examining the Court's position in its endeavours to achieve an appropriate balance between not over-

Northern Ireland: Does the System Comply With the European Convention on Human Rights? (Northern Ireland Human Rights Commission 2004) 13.

9 Oneryildiz v. Turkey, no. 48939/99, § 93, 30 November 2004. See also DJ Harris and others (n 1) 215.

10 See Osman $v$. the United Kingdom, no. 87/1997/871/1083, § 116, 28 October 1998.

11 ECHR, 'Country Profile' <http://www.echr.coe.int/Pages/home.aspx?p=pres s/factsheets\&c=> Accessed 7 July 2016. 
burdening its Member States and securing the adequate protection of the right to life.

\section{LEGAL MATERIALS AND METHOD}

The legal materials of this paper are primary and secondary legal materials. It uses the statute and conceptual approaches as well as case study approaches. Journals articles are employed by this paper to sharpen the analysis. This paper heavily lays on the European Convention on Human Rights and several relevant European cases to analyse legal problems proposed.

The research is divided into three parts, which include, firstly, the review of the evolvement of the procedural requirements of article 2 in cases of deaths arising from the acts of state agents. Secondly, it examines whether the procedural requirements of article 2 can be used as a mean in securing the adequate protection of the right to life from arbitrary killing by the use of lethal force and thirdly, it analysis the effectiveness of legal system as a procedural requirement of

${ }^{12}$ Anguelova v. Bulgaria (n 5) $§ 137$; Nachova and Others v. Bulgaria (n 5); Leonidis v. Greece (n 1) § 68; Al-Skeni v. the United Kingdom (n 5).

${ }^{13}$ See McCann and Others v. the United Kingdom (n 1) § 161; Kaya v. Turkey (n 5); Ergi v. Turkey (n 5); Çakici v. Turkey (n 1), 8 July 1999; Tanrikulu v. Turkey (n 5); McKerr v. the United Kingdom (n 1) $\S 111 ;$ Hugh Jordan v. the United Kingdom (n 1) $\S$ 105; Kelly and Others v. the United Kingdom (n 1) article 2 in the case of homicide caused by the negligence of the authorities.

\section{RESULT AND DISCUSSION}

\section{A. The Alteration of Duty to Investigate in Cases of Deaths Arising From the Actions of State Agents}

The Court imposes a duty to conduct an official investigation in the cases of deaths resulting from the actions of state agents as a procedural requirement of article 2. The fundamental purpose of investigation is to figure out whether domestic laws adequately protect the right to life as well as to ensure the accountability of the person in charge. ${ }^{12}$ When the life is taken by the use of force, the requirements of article 2 paragraph 2 of the ECHR must be satisfied. That is why an effective investigation is needed in order to review the lawfulness of the use of force. This procedural obligation applies not only to the case of homicides by the use of lethal force, ${ }^{13}$ but also to other non-lethal force cases where state agents potentially bear responsibility for loss of life ${ }^{14}$ as well as

§ 94; Shanaghan v. the United Kingdom (n 1) § 88; Anguelova v. Bulgaria (n 5); Ulku Ekinci v. Turkey (n 5); Hackett v. the United Kingdom (n 5); Nachova and Others v. Bulgaria (n 5) § 110; Ramsahai v. the Netherlands (n 5); Al-Skeni v. the United Kingdom (n 5).

${ }^{14}$ E.g. Erikson v. Italy (n 8); Oneryildiz v. Turkey (n 9). See also D Korff (n 8); DJ Harris and others, (n 1) 215 . 
killings by non-state actors. ${ }^{15}$ However, in this writing the author will only focus on examining the judgments of the Court concerning cases of deaths arising from the actions of state agents.

The Court first develops this procedural obligation in the case of McCann and Others v. the United Kingdom after interpreting obligation to protect the right to life under article 2 in conjunction with state's positive obligation to secure rights and freedoms within its jurisdiction under article $1 .{ }^{16}$ In its early jurisprudence, the Court only asserts the importance of effective investigation to assess the lawfulness of the use of force by state authorities without clarifying further the meaning of effective investigation itself. The Court asserts "it is not necessary in the present case for the Court to decide what form such an investigation should take and under what conditions it should be conducted". According to J ChevalierWatts, in this case the Court seems to be using a pragmatic approach. This mode was influenced by the abstract nature of the obligation to investigate as an implied provision; therefore the Court tends to apply a wider margin of appreciation to the states. Nevertheless, the McCann Case is a

${ }^{15}$ See Ulku Ekinci v. Turkey (n 5).

${ }^{16}$ McCann and Others v. the United Kingdom (n 1) $\S 161$.

${ }_{17}$ ibid § 162. cornerstone in assuring the accountability of state agents and prevents the arbitrary killings by the use of force.

Moreover, in the McCann Case the Court implicitly begins to recognise the importance of public scrutiny as an important part of inquest procedure by mentioning some forms of public inquest proceedings, such as: the proceedings had been public, the involvement of legal representation of victims, and the hearing of large number of witnesses (79 people). ${ }^{17}$ Therefore, in this case the Court concluded that the official investigation was sufficient. This finding was strongly critised by the applicants. They claimed that they were not equally represented in the proceedings and not all eyewitnesses were traced. ${ }^{18}$

In Kaya v. Turkey, the failure to conduct an independent investigation of the circumstances surrounding the killing of the victim has been concluded as a violation of procedural obligation of article 2. ${ }^{19}$ The case was about the killing of the applicant's brother, Mr Abdülmenaf Kaya, in a gun battle between members of the security forces and a group of terrorists. $\mathrm{Mr}$ Abdülmenaf Kaya was alleged as one of the assailants who died in the hostilities. In

\footnotetext{
18 ibid 163.

${ }^{19}$ Kaya v. Turkey (n 5) § 92. See also Ergi v. Turkey (n 5) $\S 85$.
} 
this case, the prosecutor did not conduct an effective investigation. Intentionally, he ignored any obligation or need to carry out an independent reconstruction of the killing events. He just accepted any information given by the military and did not conduct any fingerprinting to verify whether the weapon and ammunition truly belonged to the deceased. Furthermore, the prosecutor failed to investigate the validity of the allegations against the victim: was he a terrorist or just a farmer living near the battle? ${ }^{20}$

In the above, the Court seems to assess the elements of effective official investigation on the basis of case by case. ${ }^{21}$ Although in previous judgments public scrutiny and independence have become important parts of any effective official investigation that fulfills the procedural limb of article 2, the detail requirements of an effective official investigation itself are still obscure.

On 4 May 2001 the Court decided four cases from Northern Ireland, which later became an essential case law concerning the procedural requirement of article 2 in cases of deaths resulting from the actions of state agents. The judgments

20 ibid $\$ \S 88-90$.

${ }^{21}$ See Ulku Ekinci v. Turkey (n 5).

${ }^{22}$ McKerr $v$. the United Kingdom (n 1) $\$ \$ 112-5$; Hugh Jordan v. the United Kingdom (n 1) §§ 1069, 4 May 2001; Kelly and Others $v$. the United of McKerr v. the United Kingdom, Hugh Jordan v. the United Kingdom, Kelly and Others v. the United Kingdom, and Shanaghan v. the United Kingdom have clarified four important tests in determining the sufficiency of an adequate and effective investigation into alleged unlawful killing by state agents. These tests are: the independence of investigators, the effectiveness of the investigation, the promptness and reasonable expedition, and the element of public scrutiny. ${ }^{22}$ These four elements are cumulative; a failure to satisfy one of them may lead to a violation. The use of these four tests has been consistently reiterated by the Court in its recent judgments, such as in the case of Ramsahai v. the Netherlands and the case of Al-Skeni v. the United Kingdom. ${ }^{23}$

Independence means no vertical or institutional connection between the investigators or prosecutors and the alleged perpetrators. Once an incident of death involving the use of lethal force is noticed, an effective and adequate official investigation must be conducted by the authorities without waiting for any claim from the deceased relatives. The effectiveness of an investigation can be seen from whether it can assess the legality

Kingdom (n 1) $\S \S 95-8$; Shanaghan v. the United Kingdom (n 1) $\$ \S 89-92$.

${ }^{23}$ See Ramsahai v. the Netherlands (n 5); and AlSkeni v. the United Kingdom (n 5). 
of the use of force, identify and punish the offenders, and that it takes reasonable measures in securing evidence relating to the incident. ${ }^{24}$ Any deficiency, such as the lack of independence, the lack of transparency, the failure to inspect the responsible officials, the absence of legal assistance for representing the victims' family, the failure to disclose the witness statements, and the delay in inquest proceedings that has impeded the public prosecutors from obtaining sufficient evidence in order to warrant prosecution, can be concluded as a violation of the procedural limb of the right to life..$^{25}$

Furthermore, the Court extends the procedural requirement of article 2 to the incidence of deaths caused by state agents in non-lethal force cases. ${ }^{26}$ This extension is applied to medical malpractice ${ }^{27}$ and officials' negligence, ${ }^{28}$ because in such cases state institutions normally conceal the truth in a collusive manner. Hence, the investigation is addressed to ensure demonstration of evidence regarding the criminal liability of the offenders and the transparency of the actions of state officials. Uniquely, in these typical cases

${ }^{24}$ McKerr v. the United Kingdom (n 1) §§ 111-3, 157; Hugh Jordan v. the United Kingdom (n 1) $\$ \S$ 109-6, 142; Kelly and Others $v$. the United Kingdom (n 1) $\S \S 95-8,136$; Shanaghan v. the United Kingdom (n 1) §§ 89-92, 122.

25 ibid. See also Leonidis v. Greece (n 1) § 68.

${ }^{26}$ See Calvelli and Ciglio v. Italy, no. 32967/96, § 49, 17 January 2002; and Oneryildiz v. Turkey (n 9). the Court declared that the procedural obligation does not just stop at the investigation process, but how to create an effective judicial system for victims. ${ }^{29}$ If the homicide was caused by an unintentional error of judgment or carelessness by the agents of the state, it might only be fulfilled by civil, administrative or other available disciplinary sanctions. However, deaths caused by a serious negligence of the authorities can be considered as the breach of the right to life in its procedural aspect, if the state did not charge the offenders with criminal offences. ${ }^{30}$

From the above explanations it can be said that the Court, as an enforcement organ of the ECHR, has tried to be more protective of the right to life. Its innovation in its jurisprudence, concerning a state's duty to investigate cases of deaths resulting from the actions of state agents, has become an important aspect in the supremacy of the right to life. Although in its early judgments the Court seems reluctant to impose a burden on the states, by not mentioning the detail requirements of an effective investigation, the Court has

${ }^{27}$ Erikson v. Italy (n 8). See also D Korff (n 8); J Chevalier-Watts (n 8); and T McGleenan (n 8).

${ }^{28}$ Oneryildiz v. Turkey (n 9). See also DJ Harris and others (n 1) 215.

${ }^{29}$ ibid $\$ 95$.

30 ibid $\S 93$. 
come up with a progressive step in its recent judgments by clarifying the scope and content of an effective and adequate official investigation. However, the issue of whether imposing duty to investigate will become an excessive burden to the states, is still questioned. Therefore the next section will discuss this issue further.

\section{A. Examining the Court's Position in the Use of Force Cases}

The Court's progressivity in protecting the right to life is obvious. A failure to investigate homicide caused by the actions of state agents potentially results in a violation of article 2 . There is no time limit for the state to be bound by this obligation. When new evidence is found, the state has a responsibility to respond promptly and conducts a further investigation if needed. ${ }^{31}$ The Court puts quite a high standard on the protection of the right to life in the context of homicide by the use of lethal force.

Duty to investigate has become an important part of the right to life. The substantive requirement of article 2 , not to use lethal force except in certain necessary conditions, is different from the procedural

\footnotetext{
${ }^{31}$ Brecknell v. the United Kingdom, no. 32457/04, $\S \S 67-8,27$ November 2007.

${ }^{32}$ D Korff (n 8) 35.

${ }^{33}$ See McCann and Others v. the United Kingdom (n 1).
}

requirement to hold an effective official investigation into a death or deaths resulting from the actions of state agents. ${ }^{32}$ There can be a violation of a substantive requirement without a breach of procedural limb. ${ }^{33}$ There can be also a breach of procedural requirement only ${ }^{34}$ or a breach of both types of requirements. ${ }^{35}$

Recalling the significant impact of the Court's judgments, in this chapter the author will assess whether the requirement has become an unreasonable and excessive burden for the member states or not. Also, whether the Court's findings have adequately protected the right to life. The analyses will be based on four requirements of an effective and adequate official investigation that has been developed by the Court in its judgments which, as cited above, are the independence of the investigators, the effectiveness of the investigation, the promptness and reasonable expedition, and public scrutiny.

\section{The independence of the investigators}

The domestic laws of the states should be able to support the independence and impartiality of the persons responsible

\footnotetext{
${ }^{34}$ Kaya v. Turkey (n 5). See also Ergi v. Turkey (n 5).

${ }^{35}$ See Isayeva, and Others v. Russia (n 1).
} 
for conducting the investigation and prosecution. ${ }^{36}$ Impartiality becomes a compulsory part of an effective official investigation. The lack of independence may lead to a violation such as in Brecknell v. the United Kingdom. ${ }^{37}$ Moreover, in many cases, the lack of independence frequently results in the devastation of the fact-finding process. In a worst case scenario, such as Anguelova v. Bulgaria, where the deceased died in police custody, the detention register was forged and the autopsy record was modified in order to blur the cause of the skull fracture. ${ }^{38}$ Hence, the Court found a violation of article 2 due to the lack of impartiality of the investigators that lead to the omission of key evidence concerning the incidence. ${ }^{39}$

The key element of independence is the lack of hierarchical or institutional connection between the alleged perpetrators and the investigators. ${ }^{40}$ This requirement may be hard to be satisfied by the state. For example, if the death was conducted by a police officer, because sometimes the police are the only

\footnotetext{
${ }^{36}$ Nachova and Others v. Bulgaria (n 1) $§ 112$.

${ }^{37}$ Brecknell v. the United Kingdom (n 31) p 27.

${ }^{38}$ Anguelova v. Bulgaria (n 5) § 142.

39 ibid $\$ \S 145-6$.

${ }^{40}$ McKerr v. the United Kingdom (n 1) § 111; Hugh Jordan v. the United Kingdom (n 1) § 109; Kelly and Others v. the United Kingdom (n 1) §98; Shanaghan $v$. the United Kingdom (n 1) § 92.

${ }^{41}$ Hackett $v$. the United Kingdom (n 5).
}

responsible institution to carry out a criminal investigation in a particular state. However, this problem can be over-ridden by inviting a foreign investigator from another region such as in the case of Hackett v. the United Kingdom. ${ }^{41}$

\section{The effectiveness of the investigation}

As described in a previous section, the scope and content of an effective investigation consists of three aspects: i) whether it can examine the legality of the use of force; ii) whether it can identify and punish the offenders, and iii) whether the investigation has been done reasonably in order to secure the evidence in the field. From these elements it seems the Court places a high standard on the states if they are going to satisfy the requirements. However, the Court's reiteration that duty to investigate is an obligation of means, not of result, tends to lessen the degree of responsibility. ${ }^{42}$

There is not an absolute right of the applicants to gain a prosecution or conviction. ${ }^{43}$ As long as the state has conducted an investigation diligently, it

\footnotetext{
${ }^{42}$ See McKerr v. the United Kingdom (n 1) $\$ 1112-$ 3; Hugh Jordan v. the United Kingdom (n 1) §§ 1067, 4 May 2001; Kelly and Others v. the United Kingdom (n 1) §\$ 95-6; Shanaghan v. the United Kingdom (n 1) §§ 89-90; Anguelova v. Bulgaria (n 5) $\S 139 ;$ Al-Skeni v. the United Kingdom (n 5) $\S$ 166.

${ }^{43}$ Brecknell v. the United Kingdom (n 31) § 66.
} 
may fulfill the requirement of having conducted an effective investigation. This notion is confirmed by the judgment of Szula v. the United Kingdom. ${ }^{44}$ In the case of Szula the Court did not ask the state to hold a new investigation, although the police failed to gain sufficient evidence for prosecution. As with Szula, in the case of Giuliani and Gaggio v. Italy the applicants also failed to secure their claims because the state showed that it had conducted an effective investigation. The effectiveness was seen from the state's ability to assess the lawfulness of the use of force, as well as the compatibility of the planning and organisation of the killing policy with the obligation to protect life. Although the forensic doctors was failed to trace the fragment of cartridge embedded in the head of victim, the limitation of "obligation of means" does not require the investigation to be done to that extent. ${ }^{45}$ This is understandable, as long as the forensic examination was conducted transparently.

\section{The promptness and reasonableness of} expedition
It is understandable that there may be some obstacles that prevent the progress of an investigation. However, a prompt response by the authorities is essential in maintaining the effectiveness of their law enforcement system and ignoring the nasty allegations of fraud or collusion by the communities. ${ }^{46}$ In McKerr case, the delay in the inquest amounted to a violation of the procedural aspect of article 2. The expedition was not conducted in a reasonable manner, as can be seen from two aspects. First, the frequent and lengthy adjournments to the proceedings were taken without a reasonable cause. Second, the Secretary of State often used public interest immunity to prevent some enquiries or disclosure of important documents. ${ }^{47}$

In the context of investigation, how long is a delay that may be caused by any obstacles in the investigation process, before it can no longer be tolerated. This question is of course hard to answer as, among other considerations, it is uniquely contextual.

\section{Public scrutiny}

Gaggio v Italy' (2011) 11:3 Human Rights Law Review 567, 571-3.

46 See Brecknell v. the United Kingdom (n 31) $\S \S$ 65; and McKerr v. the United Kingdom (n 1) $\$ \S$ 142-55.

47 ibid $§ \S 142-55$. 
There is no doubt that the involvement of the relatives of the deceased in the investigation process designed to figure out the causes of the deaths, is vital. ${ }^{48}$ Leaving the next-of-kin without any information will torture them mentally. Therefore, since the beginning of the jurisprudence in the McCann case, the Court has asserted the importance of the participation of the families of the deceased. ${ }^{49}$

Nevertheless, the problem is how far the deceased's families can be involved in the inquest or investigation process? In the case of McCann there was no violation of procedural limb of article 2 because the next-of-kin of the deceased were sufficiently represented in the proceedings by some experienced lawyers that were able to examine and question the key witnesses, including those who were involved in the planning and conduct of anti-terrorist operations, such as police officers and military personnel. ${ }^{50}$ While, in the case of McKerr, there was a violation of the procedural aspect of article 2, since the applicants' representations were hindered from actively participating in questioning the witnesses, because they did not have access to witness statements before the appearance of the witness.

48 ibid $\S 147$.

${ }^{49}$ McCann and Others $v$. the United Kingdom (n 1).
Actually, in the case of McCann the applicants also did not have any access to the witness statements. However, as there was a change in the procedure, under new regulations (Home Office Circular No. 20/99) the Coroners were required to provide copies of the written statements or inquest documents to the interested parties, such as the deceased's families, when the deaths were caused in custody or resulted from the actions of police personnel. ${ }^{51}$ This move was addressed to assure the transparency of the investigation process. From this comparison, it can be concluded that the Court is following the national laws in interpreting the requirement of public scrutiny. In this case the focus is on the relatives of the deceased gaining access to relevant documents.

This approach is problematic because, on the one hand the Court is trying to protect the right to life, while not imposing a strict burden on the member states; but on the other hand, such action may lead to a wider application of margin of appreciation. It is feared that potentially there will be an imbalance in the standards of protection, particularly if the domestic laws of the member states do not favour the right to life.

\footnotetext{
${ }^{50}$ McCann and Others $v$. the United Kingdom (n 1).

${ }^{51}$ McKerr $v$. the United Kingdom (n 1) $§ 78$.
} 


\section{B. Duty to Investigate Non-Lethal Force Cases: Challenges and Opportunities}

Initially the Court imposed an obligation to investigate suspicious deaths arising from the actions of state agents through the use of lethal force. Then, the Court extended this obligation to cases of unexpected deaths arising from gross negligence by public authorities, such as in medical malpractice and life-threatening environmental risk. $^{52}$

Different with the deaths involving the illegitimate use of force, in non-lethal force cases the Court does not impose a duty to investigate that leads, or would lead, to a capability to prosecute the responsible agents via criminal proceedings. ${ }^{53}$ Criminal sanctions are compulsory only when the deaths were caused through gross negligence by the authorities, where / when they failed to prevent the foreseeable and imminent risk of loss of life. This principle then makes it complicated for the families of the victims of medical malpractice to secure their claim under the procedural limb of article 2 , as discussed below.

\footnotetext{
${ }^{52}$ See Erikson v. Italy (n 8); Sieminska v. Poland, no. 37602/97, admissibility judgment of 29 March 2001; Oneryildiz v. Turkey (n 9); and Calvelli and Ciglio v. Italy (n 26).
}

\section{Medical malpractice}

Although the Court has extended the procedural requirement of article 2 to deaths caused by state agents in non-lethal force cases, practically it is not easy to secure this claim before the Court. In the case of hospital fatalities, the unintended deaths do not always result in criminal proceedings against the perpetrators, because it is often hard to find a convincing evidence to prosecute the alleged perpetrators. Therefore, there should be an effective judicial system that satisfies the victims' next-of-kin, such as a compensation for damages, the publication of the judgment, and the imposition of disciplinary sanctions for those responsible. ${ }^{54}$

In some hospital fatalities cases, such as Erikson v. Italy, and Powell v. the United Kingdom, the applicants failed to secure their claims under procedural requirement of article 2 , due to the issue of admissibility. In the case of Erikson v. Italy the Court declared that the application is inadmissible due to the lack of ability to exhaust existing domestic remedies, especially concerning the applicants' failure to bring a civil action for negligence against the hospital. ${ }^{55}$ Conversely, in the

\footnotetext{
${ }^{53}$ ibid.

${ }^{54}$ Calvelli and Ciglio v. Italy (n 26) $§ 51$.

${ }^{55}$ Erikson v. Italy (n 8)
} 
case of Powell v. the United Kingdom the application was also declared inadmissible due to the applicants' acceptance of compensation in a civil claim. Hence, the applicants are no longer considered as victims under article 34 of the Convention. ${ }^{56}$ From those two judgments, the Court's position seems obscure, especially regarding the legal standing of the families of deceased medical malpractice victims bringing a claim under the procedural limb of article 2 .

By citing its verdict in the case of Powell v. the United Kingdom, the Court reiterates that the victims in the case of Calvelli and Ciglio v. Italy are no longer victims because they have received compensation as a result of civil proceeding. As a response to the decision, the judges Rozakis, Bonello and Straznicka together wrote a dissenting opinion arguing that in these typical cases so far the Court only applies a minimum protection to the right to life. ${ }^{57}$ They maintain that criminal proceedings are the most suitable for the case of unintentional death caused by medical negligence, rather than civil litigation. ${ }^{58}$ Commonly civil proceedings are more suitable for dealing with private

56 Powell v. the United Kingdom, no. 45305/99, admissibility judgment of 4 May 2000. See also Calvelli and Ciglio v. Italy (n 26) § 55.

57 Partly Dissenting Opinion of Judge Rozakis Joined by Judges Bonello and Strážnická in the case of Calvelli and Ciglio v. Italy. 58 ibid. or material matters. The fact that the families of the deceased have accepted compensation for damages does not, in essence, elapse their victim status. At least, this is what the Court has developed in its case law so far that "the obligations of the State under Article 2 cannot be satisfied merely by awarding damages". 59

The author tends to agree with the opinions of those three dissenting judges. In future the Court should move forward to reveal a more moral approach in deciding the case of an unexpected death or deaths arising from surgical falsifications. Although it means that the Court will impose a strict burden on its member states, accepting the taking of life through the negligence of medical practitioners is unreasonable, particularly if the hospital is owned by the state. The state has to set regulations within the public health institutions to provide effective deterrence and preventing threats to the right to life. Also practically, the criminal laws of some of the Convention's member states, such as Turkey and Italy, have recognised the prosecution of unintentional homicide caused by negligence. ${ }^{60}$

\footnotetext{
${ }^{59}$ McKerr v. the United Kingdom (n 1) § 121. See also Kaya v. Turkey (n 5) § 105; Yassa v. Turkey, Reports 1998-VI, § 74, 2 September 1998.

${ }^{60}$ See Cakici v. Turkey (n 1); Ergi v. Turkey (n 5); Ulku Ekinci v. Turkey (n 5) § 111; Calvelli and Ciglio v. Italy (n 26).
} 


\section{CONCLUSION AND SUGGESTION}

\section{Life-threatening environmental risks}

Oneryildiz v. Turkey was the first case before the Court dealing with the incidence of negligence caused by the authorities regarding a life-endangering condition. In its verdict the Court asserts two standards of punishment applicable in this kind of case. First, if the deprivation of life is not caused intentionally, the state has an obligation to provide an effective judicial system to compensate the victims. It can be done by awarding a certain amount of money in civil proceedings or applying administrative as well as disciplinary remedies. ${ }^{61}$ Second, the state has a positive obligation to prosecute the responsible perpetrators in criminal proceedings, if the authorities fail to take any measures to avert the loss of life, and where they have realised that the risks is imminent and foreseeable. ${ }^{62}$ Therefore, it can be said in this context the Court tries to set a more stringent standard, by including criminal sanctions in an incident of gross negligence by a state's authorities

\footnotetext{
${ }^{61}$ Oneryildiz v. Turkey (n 9) § 92.

62 ibid $§ 94$.

${ }^{63}$ McCann and Others $v$. the United Kingdom (n 1) $\S 161$.
}

Article 2 does not literally guarantee the right to have an effective investigation. Nevertheless, the Court in its verdicts develops a procedural requirement of the right to life to conduct an effective investigation. Duty to investigate emerges as a consequence, when article 2 it is read together with positive obligation of states under article $1 .{ }^{63}$ In the beginning the Court only specifies the importance of duty to conduct an effective official investigation in the cases of deaths caused by the use of lethal force. As many cases appear, then the Court extended this procedural limb of article 2 to the incidence of homicide arising from negligence of authorities, particularly in hospital fatalities and lifeendangering conduct. In both kinds of cases, the Court has a distinct approach is setting a minimum standard for the states to adhere to.

The Court applies four tests in examining whether the investigation of homicide arising from the use of force is affective and adequate or not. ${ }^{64}$ First, the investigators and prosecutors should have a certain degree of impartiality. This status

\footnotetext{
${ }^{64}$ See McKerr $v$. the United Kingdom (n 1) §§ 112-5; Hugh Jordan v. the United Kingdom (n 1) $\S \S 106-9 ;$ Kelly and Others v. the United Kingdom (n 1) $\S \S 95-8$; Shanaghan v. the United Kingdom (n 1) $\S \S 89-92$.
} 
can, at least in part, be justified by the lack of hierarchical or institutional connection to the perpetrators. Second, an effective investigation is one that leads to a conclusion of the legality of the use of force and to a capability to identify as well as punish the offenders. Third, the state should demonstrate a prompt and reasonable expedition in initiating and then carrying out its investigation. Any delay that may cause the ineffectiveness of the investigation can be concluded as a breach of article 2. Fourth, the involvement of the families of the deceased in the inquest proceedings leads to a blur in the question of how far the next-of-kin can be included.

From those four tests, the Court seems apply a high standard of investigation to protect the right to life and impose a strict obligation on the state. If one of the tests is ignored, a violation of article 2 may occur. In this context, the Court has an opportunity to develop its jurisprudence in favour of the protection of the right to life from arbitrary killings by state agents. This is justified by the provision of article 2 paragraph 2 that prohibits the taking of life by the use of force, except if absolutely necessary. There is no time limit for the state to be bound by this obligation. When new evidence is

\footnotetext{
${ }^{65}$ Brecknell v. the United Kingdom (n 31).

${ }^{66}$ Partly Dissenting Opinion of Judge Rozakis Joined by Judges Bonello and Strážnická (n 57).
}

found, the state has a responsibility to respond promptly and conduct a further investigation if needed. ${ }^{65}$ However, since the four tests are not an obligation of result, states have a certain degree of discretion as to their investigatory conduct. As long as they can demonstrate their measures, potentially there will be no violation of article 2. From that jurisprudence we can learn that the Court has tried to achieve a balance between not over-burdening its member states and protecting the right to life from arbitrary killings by the agents of those states.

Conversely, in the case of unexpected homicide caused by authorities' negligence in hospital fatalities, the Court seems reluctant to impose a burden on its states' parties and applies a minimum protection to the right to life. ${ }^{66}$ Without mentioning the detailed requirements of an effective and adequate investigation, such as in previous cases, the Court in this case maintains that if the victims have received compensation in civil proceedings, they will lose their victim status. ${ }^{67}$ This jurisprudence is totally different with the case of homicide by the use of force, where the Court stated that the procedural limb of article 2 could not be fulfilled by awarding damages in

\footnotetext{
${ }^{67}$ Powell v. the United Kingdom (n 56). See also Calvelli and Ciglio v. Italy (n 26) § 55.
} 
Brawijaya Law Journal Vol.4 No.1 2017

civil litigations. ${ }^{68}$ Therefore, in this case the Court tends to maintain its speed in producing robust judgments securing the right to life. Letting the state apply a wide range of margin of appreciation, and as long as the state has provided a compensation for its authorities' negligence, there will be no violation of article 2. From the author's perspective the court does this, because literally article 2 only prohibits intentional killings, not unintentional ones.

Interestingly, in the case of the loss of life, due to gross negligence of public authorities, and where the risks are foreseeable, the Court tends to set a stringent standard of protection to the right to life. When there is gross negligence by the authorities, the Court requires that criminal proceedings should be carried out to prosecute the responsible authorities. ${ }^{69}$ This jurisprudence is interesting, because a stringent burden on states has been implemented, although in incidents where the fatal use of force is not present.

\section{REFERENCES}

\section{Journal Articles}

Aolain FN, 'The Evolving Jurisprudence of the European Convention

\footnotetext{
${ }^{68}$ McKerr v. the United Kingdom (n 1) $§ 121$. See also Kaya v. Turkey (n 5) § 105; Yaşa v. Turkey (n 69).
}

Constitutional Issues and Indigenous Rights

Concerning the Right to Life' (2001) 19/1, Netherlands Quarterly of Human Rights

Chevalier-Watts J, Effective Investigations under Article 2 of the European Convention on Human Rights: Securing the Right to Life or an Onerous Burden on a State?' (2010) 21 3, The European Journal of International Law

Cowan A, 'A New Watershed? Reevaluating Bankovic in Light of
Al-Skeni'
(2012)
(1) 1 ,
Cambridge Journal of
International and Comparative
Law

Korff D, 'The Right to Life: A Guide to the Implementation of Article 2 of the European Convention on Human Rights' (2006) 8, Human rights handbooks

Ryngaert C, 'Claritying the Extraterritorial Application of the European Convention on Human Rights' (2012) 28/74, Merkourios

Sanctis FD, 'What Duties do States have with Regard To the Rules of Engagement and the Training of Security Forces under Article 2 of the European Convention on

\footnotetext{
${ }^{69}$ Oneryildiz v. Turkey (n 9) § 94.
} 
Brawijaya Law Journal Vol.4 No.1 2017

Human Rights?' (2006) 10 1, The International Journal of Human Rights

Skinner S, 'The Right to Life, Democracy and State Responsibility in 'Urban Guerilla' Conflict: The European Court of Human Rights Grand Chamber Judgment in Giuliani Gaggio v Italy' (2011) 11:3, Human Rights Law Review

\section{Books}

McGleenan T, Investigating Deaths in Hospital in Northern Ireland: Does the System Comply With the European Convention on Human Rights?, (Northern Ireland Human Rights Commission, 2004).

Harris DJ and others, Law of the European Convention on Human Rights, 3rd ed, (OUP, 2014).

\section{Treaties}

European Convention on Human Rights.

\section{Cases}

Al-Skeni v. the United Kingdom, no. 55721/07, 7 July 2011.

Anguelova v. Bulgaria, no. 38361/97, 13 June 2001.

Brecknell v. the United Kingdom, no. 32457/04, 27 November 2007.

Cakici v. Turkey, no. 23657/94, 8 July 1999.
Constitutional Issues and Indigenous Rights

Calvelli and Ciglio v. Italy, no. 32967/96, 17 January 2002.

Ergi v. Turkey, no. 23818/94, 28 July 1998.

Erikson v. Italy, no. 37900/97, admissibility decision of 26 October 1999

Giuliani and Gaggio v. Italy [GC], no. 23458/02, 24 March 2011.

Hackett v. the United Kingdom, no. $34698 / 04$, admissibility decision of 10 May 2005.

Hugh Jordan v. the United Kingdom, no. 24746/94, 4 May 2001.

Isayeva v. Russia, no. 57950/00, 24 February 2005.

Isayeva, and Others v. Russia, nos. 57947/00, 57948/00 and 57949/00, 24 February 2005.

Kaya v. Turkey, no. 22729/93, 19 February 1998.

Kelly and Others v. the United Kingdom, no. 30054/96, 4 May 2001.

Leonidis v. Greece, no. 43326/05, 8 January 2009.

McCann and Others $v$. the United Kingdom, no. 18984/91, 27 September 1995.

McKerr v. the United Kingdom, no. 28883/95, 4 May 2001.

Nachova and Others v. Bulgaria, nos. 43577/98 and 43579/98, 6 July 2005. 
Brawijaya Law Journal Vol.4 No.1 2017

Oneryildiz v. Turkey, no. 48939/99, 30 November 2004.

Osman v. the United Kingdom, no. 87/1997/871/1083, 28 October 1998.

Powell v. the United Kingdom, no. 45305/99, admissibility judgment of 4 May 2000.

Ramsahai $v$. the Netherlands, no. 52391/99, 15 May 2007.

Shanaghan v. the United Kingdom, no. 37715/97, 4 May 2001.
Constitutional Issues and Indigenous Rights

Sieminska v. Poland, no. 37602/97, admissibility judgment of 29 March 2001.

Szula v. the United Kingdom, no. 18727/06, 4 January 2007.

Tanrikulu v. Turkey, no. 23763/94, 8 July 1999.

Ulku Ekinci v. Turkey, no. 27602/95, 16 July 2002.

Yaşa v. Turkey, Reports 1998-VI, 2 September 1998. 